\title{
SELF(IE)-ESTEEM? - A MANIFESTATION OF ADOLESCENT SELF-CREATING ENDEAVOURS IN THE VIRTUAL SPACE OF FACEBOOK
}

\author{
LILI FEJES-VÉKÁSSY \\ Péter Pázmány Catholic University

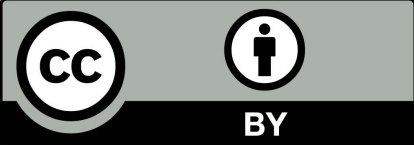 \\ Faculty of Humanities and Social Sciences, Institute of Psychology, \\ Mikszáth Kálmán tér 1, 1088 Budapest, Hungary \\ E-mail: fejes.vekassy.lili@gmail.com
}

\begin{abstract}
At the centre of our interest stand the manifestations of adolescent self-creating endeavours in virtual space of the social media portal called Facebook. Frequent selfphotography (selfie) making, as a pronounced cultural feature of contemporary youth, and regular activity on Facebook handled as tightly connected factors; we propose that youngsters, bearing these attributes, have a different self-esteem than those adolescents who rarely or never take any photographs of themselves. In the first, quantitative part of our research the participants $(\mathrm{N}=80)$ filled in the Rosenberg Self-Esteem Scale and a questionnaire containing questions in connection with Facebook-usage (compiled by us). In the qualitative part of the research the participants took part in a half-structured interview, containing questions in connection with selfie-making (also compiled by us). Our hypothesis was not proven by statistical analysis, no connection could be identified between frequent selfie-making and low self-esteem.
\end{abstract}

Key words: selfie, self-esteem, adolescence, social media, Facebook

\section{THE CORE QUESTIONS OF ADOLESCENCE}

"Who am I?" - to answer this question is one of the fundamental problems of adolescence. During this period youngsters show more effort than ever to discover, understand and observe themselves (Mérei, 1993; Clauss and Hiebsch, 1980). Because of the emphasized attention attributed to themselves adolescents are likely to believe that others provide the same importance to them (Elkind, 1967); therefore, they care increasingly about their appearance and interactions. It can also be classified as a key change of adolescence that teenagers spend most of their time without parental or teacher supervision, in each other's company thus peer relations become the primary reference (Dacey and Kenny, 1994). 


\section{BODY SCHEMA AND CAMERA}

The changes occurring in physical appearance affect the adolescents' selfesteem however it is important to underline the gender differences in this regard. Girls attribute more significance to physical appearance than boys therefore are less satisfied with their qualities (Collins and Kuczaj, 1991). To fraternize their "new" appearance adolescents endeavour to represent it as attractively as possible - this phenomenon is true for both sexes. Even hourlong standing in front of the mirror could be mentioned as a typical manifestation of this phenomenon, while youngsters gaze and explore themselves to create the most appealing visual experience. This practice has not changed up to the present day but has been supplemented by: portable digital cameras or smart phones with built-in cameras since the beginning of this decade. The numerous photographs created this way assist teenagers to accept their continuously changing body schema, over and above what they can represent themselves as in the virtual spaces of social media.

\section{WHAT IS "SELFIE"?}

The Oxford Dictionaries chose selfie as Word of the Year for 2013; the definition of this term is as follows: "a photograph that one has taken of oneself, typically one taken with a smart phone or webcam and shared via social media" (http://www. oxforddictionaries.com/definition/english/selfie?q=selfie). According to Jim Krause, one of the first theoreticians of this topic, the selfies' most appealing features are their simplicity, i. e. anybody, anywhere and anytime can take one with the appropriate equipment (Krause, 2005). Self-photography can be described as an evident cultural phenomenon of our age, which is not limited to the group of adolescents; statesmen and celebrities are taking selfies as well as everyday people who document their moments of life via this particular activity. Now many types of selfies can be distinguished, e. g. showing only the legs ("legsie") or the hair ("helfie") of the maker etc. "But first, let me take a selfie!" - it is a widespread and essential habit among youngsters to make a selfie before or during every important moment and event (http:/ / blog.oxforddictionaries. com/2013/11/word-of-the-year-2013-winner/).

The development of digital imaging and the fact that these devices became common made it possible for this phenomenon to become part of everyday life. A kind of interaction could be observed between technology and the selfie, which are facilitating each other. It is important to stress the unity of these images and social media sites. If a selfie is taken it is often meant to be uploaded to a virtual space e. g. Instagram or Facebook.

\section{ONLINE PERSONALITY VERSUS REAL SELF}

Presence on Facebook has become inseparable from the life of adolescents living in western societies; spending time and communicating on social media 
sites is part of their regular activities (Back, Stopfer, Vazire, Gaddis, Schmukle, Egloff, \& Gosling, 2010). This statement is also appropriate for Hungarian youngsters: in the first part of 2013 nearly half of the population i. e. 4.6 million people were active users of Facebook, 13\% of that were of the 13-17 age group (http:/ / kozmedia.blogspot.hu/2013/07/7-kal-nott-magyar-aktiv-facebook. html). Because appearance in virtual space is easier to construct and handle than in real life, adolescents have more possibilities and greater freedom of choice for communicating their internal and external qualities, giving them the chance to decide who they want to be - up to a certain level (Calvert, 2002; Wallace, 2006).

On taking a deeper insight into the topic one may find opposing research results. According to Back et al. (2010) the explanation behind the popularity of Facebook is that users can communicate their real selves through it. Another result states the opposite: the information shared on the internet is slightly or totally idealized for the sake of a good impression. In the researchers' opinion the impressions brought up by Facebook-profiles differ from those of reallife situations (Manago et al., 2008). A study of 2013 indicates that users who regularly post selfies expect acknowledgement, social support and intimacy in exchange (Houghton, Joinson, Caldvell, \& Marder, 2013). This suggests that the seeking for positive feedback makes the shared content idealized.

\section{HYPOTHESIS}

In the light of the above mentioned the goal of the present study was to explore the connection between selfie-uploading activity on Facebook and tendencies in self-esteem. Furthermore we also attempted to get a deeper insight to the consciousness and motivations of selfie-taking. Our hypothesis was as follows:

$\mathbf{H}$ : Among our participants those who spend more time on Facebook than the mean of the sample and upload selfies frequently have lower self-esteem than those who also spend much time on Facebook but with different activities.

\section{METHOD AND MATERIALS}

Our participants $(\mathrm{N}=80)$ came from two high schools in Budapest, Hungary. The pupils' ages ranged from 14 to $18(\mathrm{M}=29, \mathrm{~F}=51)$. We focused our research on those participants who spend more time on Facebook than the mean of the sample. This was divided by the habit towards selfies: (1) frequent selfie uploaders (2) users looking for different activities.

The quantitative phase of data collecting contained two questionnaires. First the participants filled out a questionnaire which was compiled by us. The items were connected with Facebook-usage. We asked the participants about the following: the length of Facebook membership, the average time spent on Facebook per day, the characteristics of activities, what Facebook means for them and selfie-uploading habits. Secondly the participants filled out the Rosenberg Self-esteem Scale (Hungarian translation: Gerevich et al., 2012). In 
the qualitative section of the research we selected the most selfie-uploading participants (two 17 year old girls) who took part in a half-structured interview. The questions were connected to the motivations and details of selfie-making. We asked the interviewees the following: what impressions they would like to arouse with the pictures, why do they like to take selfies, do they use retouching, what are the circumstances of taking a photo and how do they imagine their "dream" Facebook profile picture.

\section{RESULTS AND EXPLANATION}

The results of descriptive statistics gained from the questionnaire about Facebook-usage outlined well the importance of presence and activity on Facebook, together with taking selfies. The overwhelming majority of the participants $(96 \%)$ had been members of Facebook for multiple years. Also a significant proportion of the sample $(25 \%)$ spends more than 3 hours a day on Facebook. For most of the responders $(91.75 \%)$ the communication aspects of Facebook have the greatest importance. 73\% said that Facebook had become part of their everyday lives. A remarkable amount of participants $(65 \%)$ observes and likes multiple times a day the activities of their friends; $37 \%$ uploads selfies with the same frequency. At least 11 photographs on Facebook per profile were taken by the owner in the case of more than three quarter $(77,5 \%)$ of the sample. $54,5 \%$ upload an appealing picture on Facebook immediately after taking it. $24 \%$ of profile pictures are selfies. Most of the participants $(33 \%)$ change their profile picture once in 3-5 months (Table 1).

\section{Table 1}

Most common characteristics of Facebook usage and selfie taking with their frequency among participants, indicated in percentages.

\begin{tabular}{lc}
\hline \multicolumn{1}{c}{ Activity } & Percent \\
\hline Member of Facebook for more than a year. & $96 \%$ \\
\hline Spends more than 3 hours a day on Facebook. & $25 \%$ \\
\hline $\begin{array}{l}\text { The communication aspects of Facebook have the greatest } \\
\text { importance. }\end{array}$ & $91,75 \%$ \\
\hline Facebook has become part of everyday life. & $73 \%$ \\
\hline Observes and likes multiple times a day the activities of friends. & $65 \%$ \\
\hline Uploads selfies multiple times a day. & $37 \%$ \\
\hline Facebook profile contains 11-20 selfies. & $77,50 \%$ \\
\hline $\begin{array}{l}\text { If an appealing picture is taken it is uploaded to Facebook } \\
\text { immediately. }\end{array}$ & $54,50 \%$ \\
\hline Profile picture is a selfie. & $24 \%$ \\
\hline The frequency of Facebook profile picture changing is 3-5 months. & $33 \%$ \\
\hline
\end{tabular}


Before the statistical analysis was done in the compared sub-groups, the distribution of the dependent variable i. e. the data from Rosenberg Self-esteem Scale was verified. The normal distribution enabled paired-samples T-Test to be done with the data gained from Rosenberg Self-esteem Scale of participants who are frequent selfie uploaders and those who are not (Table 2). The results are as follows: $t=0,119 p=0,906$ - ergo no connection could be deduced between frequent selfie-making and low self-esteem.

\section{Table 2}

Rosenberg Self-esteem Scale means of participants who spend more time on Facebook than the mean of the sample, divided by selfie-taking habits.

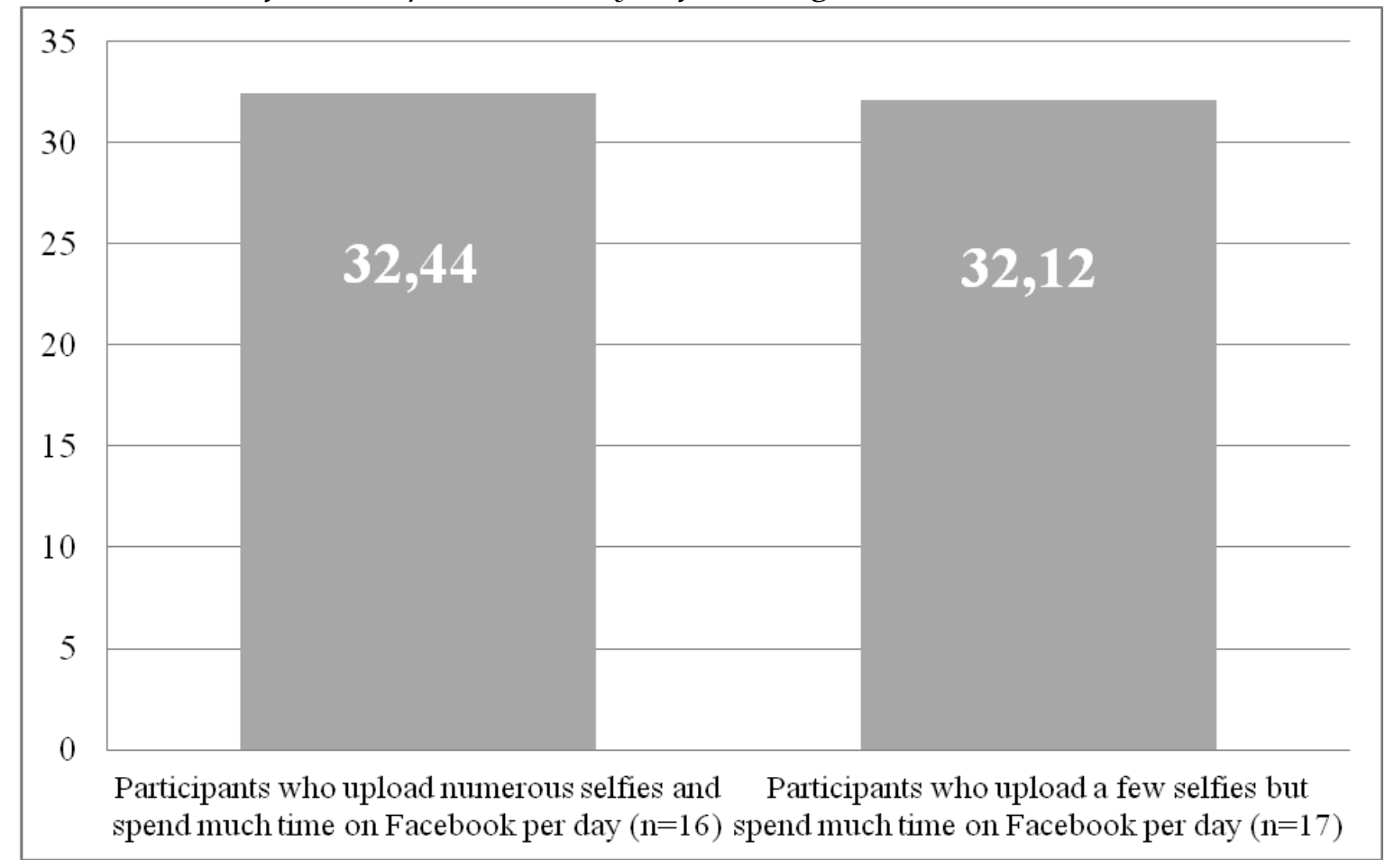

Regarding the topic of the research, questions of item 8 in questionnaire about Facebook-usage were the most important, which are completely about selfie-taking and uploading habits. Cronbach's $a=0,746$ which means high reliability of this question group.

The data gathered from the interviews point to selfie-taking having become part of everyday life for youngsters and carries numerous functions. This activity allows documenting what is remarkable for them. Furthermore selfietaking has become a free-time activity as well. It is also a new way to explore the physical appearance. At the same time it can be observed that there is a certain difference between the impression served by selfies and the real self. Both interviewees attribute themselves a more negative character according to their selfies and agree in that personal encounter would give a positive alteration compared to the photographs. The girls usually use their smart phones to take selfies thus their "dream" profile picture would be a photograph taken by a professional. 


\section{DISCUSSION AND FURTHER RESEARCH}

Our research confirmed that Facebook for contemporary adolescents has become a space for presenting their own visual contents. Youngsters use this virtual space confident where they can express, show and represent themselves to their peer relations. Our hypothesis was not proven but because of the explorative nature of the study it should be handled as an important result. Selfie-taking is an activity of making good impressions however the motivation behind it is probably not the lowness of self-esteem but the strengthening of the satisfaction with the self.

The present study could be a great starting point for future researches e. g. to get a more accurate picture about the background of selfie-taking and uploading using deeper interviews. It would also be interesting to make interviews with youngsters not taking selfies. Finally we did not have the opportunity to take a look at the Facebook-profiles of the participants; these are only known through the interpretation of the owners which could be also mentioned as an unexplored field in this topic. To summarise, the selfie-phenomenon is an actual and relevant issue which is worthy of empirical studying because present research has only illuminated a tiny part of it.

\section{REFERENCES}

1. Back, M. D., Stopfer, J. M., Vazire, S., Gaddis, S., Schmukle, S. C., Egloff, B., \& Gosling, S. D. (2010). Facebook Profiles Reflect Actual Personality, Not Self-Idealization. Psychological Science, 21. 372-374.

2. Calvert, S. L. (2002). Identity Construction on the Internet. In: Calvert, S. L., Jordan, A. B., \& Cocking, R. R. (ed.): Children in the Digital Age - Influences of Electronic Media on Development. Praeger Publishers, London.

3. Collins, W. A., \& Kuczaj, S. A. (1991). Developmental Psychology - Childhood and Adolescence. Macmillan Publishing Company, New York.

4. Dacey, J., \& Kenny, M. (1994). Adolescent Development. WCB Brown \& Benchmark Publishing Company, Virginia.

5. Clauss, G., \& Hiebsch, H. (1980). Gyermekpszichológia [Child Psychology]. Akadémiai Kiadó, Budapest.

6. Elkind, D. (1967). Egocentrism in Adolescence. Child Development, 38. 1025-1034.

7. Gárdos, A. 7\%-kal nőtt a magyar aktív Facebook felhasználók száma 2013 első félévében [The number of Hungarian active Facebook users increased by $7 \%$ in the first half of 2013]. Retrieved July 8, 2013 from: http:/ / kozmedia.blogspot.hu/2013/07/7-kal-nott-magyar-aktiv-facebook.html

8. Gerevich J., Bácskai E., Czobor P., Öberg, D., Kó J., Haack, M.-J., Matuszka B., \& Rózsa S. (2012). Korszerü addiktológiai mérőmódszerek [Advanced Addiction Measurement Methods]. Semmelweis Kiadó, Budapest, 141-148, 297.

9. Houghton, D., Joinson, A., Caldvell, N., \& Marder, B. (2013). Tagger's Delight? Disclosure and Liking Behaviour in Facebook: The Effects of Sharing Photographs Amongst Multiple Known Social Circles. University of Birmingham Discussion Paper, 2013. 03. 1-34.

10. Krause, J. (2005). Photo Idea Index. F+W Publications, Cincinnati. 148.

11. Manago, A. M., Graham, M. B., Greenfield, P., \& Salimkhan, G. (2008). Self-presentation and Gender on MySpace. Journal of Applied Developmental Psychology, 29, 446-458.

12. Mérei F. (1993). Az önismereti érzékenység a serdülókor kezdetén [Self-awareness at the beginning of adolescence]. In: Kósa É., Ritoókné Á. M. (ed.): Fejlődés-lélektani szöveggyüj- 
temény [Development Psychology Text Anthology]. Nemzeti Tankönyvkiadó, Budapest, 141-470.

13. Selfie. In Oxford Dictionaries (2013). Retrieved from: https://en.oxforddictionaries.com/ definition/selfie

14. The Oxford Dictionaries Word of the Year 2013 is 'selfie'. (2013). Retrieved November 18, 2013 from: http:/ / blog.oxforddictionaries.com/2013/11/word-of-the-year-2013-winner/

15. Wallace, P. (2006). Az internet pszichológiája [The Psychology of the Internet]. Osiris Kiadó, Budapest. 